\title{
A Legacy of Excellence in Research and Service
}

In 1961, Dr. Lourdes Manahan, a young internist at the Philippine General Hospital, presented her paper entitled "Rheumatic disease in the Philippines" at the Australian Rheumatism Congress in Sydney. ${ }^{1}$ This was the first time an article on the Philippine rheumatology experience was presented at an international convention. It was, however, not Dr. Manahan's first foray into research. In 1948, she was published in this very journal - a report on familial non-hemolytic jaundice, a syndrome which would later bear her name, the Rotor-Manahan-Florentin syndrome. ${ }^{2}$ Her interest soon shifted towards a new field of study centered on diseases referred to then as "rheumatism." After training in the United States for a year, she established an arthritis clinic to serve Filipino rheumatic patients in the PGH dispensary. For over a decade, she cared for patients alone, painstakingly documenting her findings in pages of handwritten notes and tables. These pages turned into scientific publications, and Dr. Manahan became a pioneer in research in rheumatology in the region. She was the first to describe gout in the Philippines. ${ }^{3,4}$ She authored the COPCORD (Community Oriented Program for Control of Rheumatic Diseases) studies, a joint effort by the World Health Organization and International League Against Rheumatism to measure the burden of arthritis and disability in the community.,

The Division of Rheumatology continues this legacy. Research in rheumatic diseases has been one of the core disciplines of the division over its now 50 years of existence. In celebration of our founder's $100^{\text {th }}$ birth anniversary, this special issue of ACTA MEDICA PHILIPPINA republishes three of Dr. Manahan's earlier works. The first is a report of a family with RotorManahan-Florentin syndrome. ${ }^{7}$ While not a rheumatic disease, her encounter with this condition sparked her interest in scientific inquiry. Dr. Manahan also co-authored the first clinical and laboratory description of Chikungunya in the Philippines. ${ }^{8}$ She also was one of the first to investigate HLA antigens in Ankylosing Spondylitis in Filipinos. ${ }^{9}$

This special issue in rheumatology also presents interesting cases in rheumatic diseases and original studies by the faculty of the division and its graduates. The gout registry feasibility study emphasizes the importance of databases in collecting data over time to describe the clinical profiles and outcomes of Filipino patients with gout. Penserga and Penserga's paper shines a spotlight on the unmet need to manage rheumatoid arthritis in the Philippines, where most patients do not have access to biological treatments. Finally, Villanueva-Misa et al. demonstrate the Knee Injury and Osteoarthritis Outcome Score (KOOS) to be a valuable tool for measuring disability in Filipino patients with osteoarthritis in clinical practice and research.

As we honor the legacy of the first among us, we are reminded that the central focus of our work, both in research and clinical practice, is always in the service of the Filipino patient.

\author{
Anna Kristina Gutierrez-Rubio, MD \\ Division of Rheumatology \\ Department of Medicine \\ Philippine General Hospital \\ University of the Philippines Manila
}

\section{REFERENCES}

1. Manahan L. Rheumatic Disease in the Philippines. in Australian Rheumatism Congress. 1964. Sydney.

2. Rotor AB, Manahan L, Florentin A. Familial Non-hemolytic Jaundice with Direct Van Den Bergh Reaction. Acta Med Phil. 1948; 5:37.

3. Manahan L. Is Gout Found in the Philippines? Acta Med Philipp. 1954; 10: 477-82

4. Manahan L. Uric Acid in Diabetic Filipinos. Acta Med Philipp. 1964; 1:11-4.

5. Manahan L, Caragay R, Muirden KD, Allander E, Valkenburg HA, Wigley RD. Rheumatic Pain in a Philippine Village. A WHOILAR COPCORD Study. Rheumatol Int. 1985; 5:149-53.
6. Wigley RD, Manahan L, Muirden KD, Caragay R, Pinfold B, Couchman KG, et al. Rheumatic Disease in a Philippine Village. II: A WHO-ILAR-APLAR COPCORD Study, Phases II and III. Rheumatol Int. 1991; 11: 157-61.

7. Poblete PF, Reyes M, Manahan L, Dalmacio-Cruz A. Rotor's Syndrome: A Family Study. Acta Med Phil. 1967; 4: 64-71.

8. Reyes, MP, Caviles AP, Manahan L, Espiritu-Campos L, Campos P. Clinical and Laboratory Study of a Newly Observed Viral Infection in the Philippines: A Preliminary Report. Phil J Intern Med. 1968; 5: 74-9.

9. Manahan L, Chavez C, Pascasio FM. HLA Antigens in Filipinos with Ankylosing Spondylitis. Phil J Intern Med. 1986; 24:187-90. 